włocławskiego, płockiego, krakowskiego, wroclawskiego i lubuskiego oraz biskupstwa litewskie-wileńskie i żmudzkie. $\mathrm{Na}$ ich terenie obowiązywało jednolite ustawodawstwo. Rożważania te przeprowadzono na tle europejskim, wykorzystując europejskie analogie do lepszego naświetlenia i interpretacji skapych polskich źródeł. Wykorzystano również analogie innego rodzaju, mianowicie te odnoszące się do szkół innego typu - kolegiackich, zakonnych i parafialnych.

Pracę rozpoczyna autor od przedstawienia genezy i głównych kierunków rozwojowych szkół katedralnych. Następnych kilka rozdziałów poświęconych jest osobom w nich nauczającym lub opiekującym się tymi szkołami - biskupowi jako przełożonemu szkoły oraz mecenatowi kapituł katedralnych, scholastykom katedralnym, rektorom, nauczycielom pomocniczym i lektorom teologii i prawa kanonicznego. Część poświęcona programowi szkół katedralnych podzielona jest na nauczanie na poziomie elementarnym i średnim. Podstawę nauczania w szkołach katedralnych stanowiło studium 7 sztuk wyzwolonych - trivium i quadrivium, przy czym powszechną praktyka było koncentrowanie się głównie na trivium i zaniedbywanie quadrivium. Kolejna część omawia metody nauczania. Podstawowymi formami pracy byly wykłady, ćwiczenia i dysputa. Ostatnia wreszcie dotyczy uczniów szkół katedralnych - omawia ich wiek i liczbę, długość trwania nauki, pochodzenie $i$ in. Autor odwohuje się do źródeł $\mathrm{i}$ literatury zarówno polskiej, jak i obcej, starając się, jak to we wstępie zapowiedział, skromne polskie źródła wzbogacić wiedzą pochodzącą $z$ innych terenów, przez co dzieje naszych szkół katedralnych stały się bardziej czytelne i wyraziste, a ponadto czytelnik dostrzega ich europejski rodowód i powiązania.

W zakończeniu autor daje zwięzłe podsumowanie pracy oraz próbuje ukazać rolę, jaką odegrały szkoły katedralne w kształtowaniu duchowieństwa w okresie średniowiecza.

Pracę uzupełnia indeks osób i geograficzny.

Jest to praca $\mathrm{z}$ pewnością potrzebna, tak jak niezbędne jest wznowienie $\mathrm{i}$ poszerzenie badań nad polskim szkolnictwem czasów średniowiecza - tematyką, która nie cieszy się wśród naszych badaczy szczególną popularnością. Praca ta pomoże $z$ pewnością w lepszym poznaniu dziejów szkolnictwa polskiego okresu średniowiecza $\mathrm{z}$ jednej strony, $\mathrm{z}$ drugiej zaś - w poznaniu procesu ksztalcenia polskiego duchowieństwa w tym okresie.

\title{
Z dziejów szkolnictwa jezuickiego w Polsce. Wybór artykulów, Kraków 1994, ss. 258.
}

Wydana w ubiegłym roku praca poświęcona dziejom szkolnictwa jezuickiego w Polsce wypełnia w jakimśs stopniu lukę, jaka do tej pory istniała $w$ polskiej literaturze poświęconej naszej przeszłości. Istniejące podstawowe prace Stanisława Bednarskiego i Stanisława Załęskiego powstały na tyle dawno, że są trudno dostępne, a nowsze, to najczęściej niewielkie objętościowo i rozproszone szkice ( $\mathrm{z}$ wyjątkiem rzecz jasna fundamentalnej pracy Ludwika Piechnika o Akademii Wileńskiej). Od dawna więc odczuwano potrzebę przygotowania nowoczesnego i szerzej dostępnego opracowania dziejów szkolnictwa jezuickiego i ich znaczenia w naszej kulturze i historii. W pewnym sensie takie zapotrzebowanie zaspokaja niniejsza książka, która wprawdzie nie jest całkowicie nowym opracowaniem lecz stanowi wybór szkiców z dziejów szkolnictwa jezuickiego, które już wcześniej ukazały się na lamach rozmaitych periodyków naukowych lub w pracach zbiorowch.

Większość z zebranych artykułów napisał ks. Ludwik Piechnik SJ. Prócz tego mamy w zbiorze prace ks. Stanislawa Bednarskiego SJ, ks. Bronisława Natońskiego SJ i ks. Jana Poplatka SJ. „Nie tworzą one systematycznej historii szkolnictwa jezuickiego w Polsce, ale ukazują główne etapy rozwoju i zapoznają z różnymi typami szkół” ( $z$ przedmowy). 
Po wstępie autorstwa ks. Jerzego Paszendy SJ, który zajął się również wyborem i redakcją tomu, zamieszczono kilka mapek ilustrujących chronologiczny rozwój sieci szkół jezuickich na ziemiach Rzeczypospolitej oraz spis tychże szkół w porządku chronologicznym i alfabetycznym.

Prace rozpoczynają szkice dotyczące ogólnie szkolnictwa jezuickiego - jego podstawowych zasad (S. Bednarski), nowych elementów wniesionych przez Towarzystwo Jezusowe do szkolnictwa polskiego XVI wieku (L. Piechnik) i wreszcie znany szkic Bronisława Natońskiego nt. szkolnictwa jezuickiego w Polsce w okresie kontrreformacji. Kolejny „blok” poświęcony jest jezuickim seminariom nauczycielskim na ziemiach polskich (B. Natoński, L. Piechnik) oraz alumnatowi wileńskiemu (J. Poplatek).
Następny - jezuickiemu szkolnictwu wyższemu; w tej części znajdujemy obok artykulów poświęconych Akademii Wileńskiej (L. Piechnik), również rozprawy dotyczące projektowanej akademii wojskowej Bartłomieja Wąsowskiego (L. Piechnik), prób przekształcenia braniewskiego kolegium w uniwersytet (L. Piechnik) oraz warszawskiego Collegium Nobilium (L. Piechnik). Na zakończenie zamieszczono szkic dotyczący przemian w szkolnictwie jezuickim w XVIII wieku (L. Piechnik) oraz stosunkowi Towarzystwa do Komisji Edukacji Narodowej (B. Natoński).

Prace uzupełnia bibliografía poświęcona historii szkolnictwa jezuickiego, noty o autorach oraz indeks.

\section{Publikacje zwarte 1994-1995}

\begin{abstract}
Akademia Zamojska i jej tradycje, Referaty przygotowane na sesje naukowq zorganizowang dla upamietnienia 400 rocznicy utworzenia przez Jana Zamoyskiego Akademii Zamojskiej, 27 - 28 maja 1994 w Zamościu, red. Szyszka B, Zamość 1994, ss. 147;
\end{abstract}

Album studentów Akademii Zamojskiej 1595-1781, oprac. Gmiterek H., Warszawa 1994, ss. 604;

August Cieszkowski, Wielkopolanin i Europej$c z y k$, pod red. Goryńskiej-Bittner B. i Stepnia J., Poznań 1994, ss. 185;

Bibliografia prac Bogdana Suchodolskiego, Warszawa 1994 , ss. 138 ;

Budzewicz Z, Ksztalcenie literackie w szkolach zawodowych w l. 1918-1939, Kraków 1994, ss. 146;

Górski J. J., Rzecz o Liceum św. Augustyna, Warszawa 1994, ss. 274;

Grzywna J., Guldon Z, Możdżeń S., Podstawy warsztatu historyka oświaty, Przewodnik me- todyczny do prac magisterskich, Kielce 1994, ss. 140 ,

Hausner W., Krakowski skauting 1910-1914, Kraków 1994, ss. 189;

Helena Radlinska - portret pedagoga (rozprawy, wspomnienia, materialy, red. I. Lepalczyk, B. Wasilewska, Lódź 1994 (Folia Paedagogica et Psychologica 34), ss. 230.

Hellwig J., Rola Towarzystwa Naukowej Pomocy im. Karola Marcinkowskiego w awansie spoleczno-zawodowym mlodzieźy polskiej, Poznań 1994, ss. 120;

Hellwig J., Prolegomena do historii wychowanta, Poznań 1995, ss. 124;

Hellwig J., Jamrożek W., Żołądź D., Z prac poznańskich historyków wychowania, Poznań 1994, ss. 142;

Historia wychowania, Skrypt dla studentów studiów dziennych $i$ zaocznych, red. Hellwig J., Poznań 194, ss. 146; 